$\mathrm{JPH}$, April 2022, 7(1), 1-14

Research Article -Araştırma Makalesi

DOI; 10.54409/hod.1004455

\title{
RELIABILITY AND VALIDITY ANALYSIS OF THE OBSTETRIC TRIAGE ACUITY SCALE
}

\section{Esma GÜLTÜRK ${ }^{1}$ iD Kamile KABUKCUOĞLU²}

\begin{abstract}
Objective: Obstetric triage is used for timely and appropriate assessment of pregnant women to prioritize, improve patient flow and improve patient safety. It was aimed to test the Turkish validity and reliability of the Obstetric Triage Acuity Scale (OTAS).
\end{abstract}

Material and Method: The validity-reliability study of the Obstetric Triage Acuity Scale was conducted with 10 triage nurses and 160 obstetric emergency scenarios. The data were collected using the Personal Features Questionnaire and the Obstetrics Triage Acuity Scale. Data were evaluated using kappa analysis.

Results: Obstetrics Triage Acuity Scale was found as simple kappa: 0.7956 and weighted kappa: 0.9185. Obstetrics Triage Acuity Scale is a reliable and valid instrument.

Conclusions: The Obstetric Triage Acuity Scale is a five-category triage tool suitable for use in the triage section of the emergency department.

Keywords: Obstetric Triage, Obstetric Triage Acuity Scale, Triage

\section{OBSTETRİK TRIYYAJ ACILIYYET SKALASI TÜRKÇE GEÇERLİK VE GÜVENİLİK ÇALIŞMASI}

ÖZ

Amaç: Obstetrik triyaj, hasta akışını önceliklendirmek, iyileştirmek ve hasta güvenliğini artırmak için gebelerin zamanında ve uygun şekilde değerlendirilmesi için kullanılmaktadır. Obstetrik Triyaj Aciliyet Skalası'nın (OTAS) Türkçe geçerlik ve güvenilirliğinin test edilmesi amaçlandı.

Gereç ve Yöntem: Obstetrik Triyaj Aciliyet Skalası'nın geçerlik-güvenirlik çalışması, 10 triyaj hemşiresi ve 160 obstetrik acil senaryosu üzerinden yapılmıştır. Veriler, Kişisel Özellikler Soru Formu ve Obstetrik Triyaj Aciliyet Skalası kullanılarak toplanmıştır. Veriler kappa, ki-kare, spearman korelasyon analizi kullanılarak değerlendirilmiştir.

\footnotetext{
${ }^{1}$ Corresponding Author/Sorumlu Yazar, Dr., Akdeniz University, Scholl of Health Vocation, Antalya, Turkey, egulturk@akdeniz.edu.tr

${ }^{2}$ Prof. Dr., Akdeniz University, Faculty of Nursing, Antalya, Turkey, kkamile@akdeniz.edu.tr

Submission Date/Makale Geliş Tarihi; 04.10.2021

Accepted Date/Kabul Tarihi; 09.02.2022

Permission was obtained from Akdeniz University Clinical Research Ethics Committee for the study (09/08/2017- 469).
} 
$\mathrm{JPH}$, April 2022, 7(1), 1-14

Bulgular: Obstetrik Triyaj Aciliyet Skalası basit kappa: 0.7956 ve ağırlıklı kappa: 0.9185 değeri bulunmuş̧ur. Triyaj personeli tarafindan yapılan triyaj değerlendirmesi ile Obstetrik Triyaj Aciliyet Skalası ile yapılan triyaj değerlendirme sonuçlarının $0.588^{\prime}$ lik pozitif yönlü ve istatistiksel olarak oldukça anlamlı bir ilişki olduğu saptandı (ki-kare $=154.360, \mathrm{p}<.0001)$.

Sonuç: Obstetrik Triyaj Aciliyet Skalası, acil servisin triyaj bölümünde kullanıma uygun beş kategorili bir triyaj aracidir.

Anahtar Kelimeler: Obstetrik Triyaj, Obstetrik Triyaj Aciliyet Skalası, Triyaj

\section{INTRODUCTION}

The triage in obstetrics was first used in the late 1980s and early 1990s. Obstetric triage units have been established for various reasons such as the increasing number of obstetric patients, need for a more efficient use of medical personnel and resources, and a better evaluation of fetal and maternal care (Angelini and LaFontaine, 2017). The Association of Women's Health, Obstetrics and Neonatal Nurses (AWHONN, 2014) in the United States defines obstetric triage as a "brief, thorough and systematic maternal and fetal assessment" that enables a quick evaluation of pregnant women and their fetus. Triage has become an elemental component of obstetric practices to increase bed capacity in hospitals, reduce admission duration, prevent redundant admission and standardize patient assessment (Evans et al., 2015). However, obstetric triage is conducted to ensure a timely and appropriate assessment of pregnant women to determine care priorities, improve patient flow and ascertain patient safety (Paisley et al., 2011). Obstetric triage has proved itself as a major critical perinatal service in the United States for more than two decades (Angelini and LaFontaine, 2017).

The key to providing good care for the mother and fetus is establishing interdisciplinary collaboration and communication between health professionals. Otherwise, it may have adverse effects on the mother and fetus (Chagolla et al., 2013). Timely assessment and appropriate treatment are essential components of a safe and efficient obstetric triage care. Once a pregnant woman is admitted to the emergency unit, the triage of the patient must have the utmost priority regardless of her health problem (Chagolla et al., 2013). Royal College of Obstetricians and Gynaecologists (RCOG), recommends that any pregnant woman who is admitted to the emergency unit be immediately evaluated by a midwife, nurse or obstetrician (Panicker, 2014). Meanwhile, the Emergency Nurses Association (ENA, 2011) further suggests that pregnant women must receive the best care by well-trained medical staff to protect the pregnant women and the fetus. In case of emergency obstetrics, it is definitely necessary to develop an obstetric 
$\mathrm{JPH}$, April 2022, 7(1), 1-14

triage scale specific to obstetric emergencies to ensure an early and appropriate intervention by the medical team. It has been often reported that there is no available categorization system on a national scale in Turkey for the standardization of obstetric triage of patients who are admitted to the emergency unit. To this end, this study tests Obstetrical Triage Acuity Scale (OTAS) for validity and reliability in Turkey.

\section{MATERIALS AND METHODS}

\section{Participants}

The study data were collected between 01 January- March 30, 2018 in the Triage Unit of Akdeniz University Hospital Emergency Service where every month, on average, 310 patients with obstetric complaints are admitted to the emergency service and the triage nurse assesses the patient's acuity based on the Triage and Color Coding designed by the Ministry of Health in Turkey.

The study universe was composed of patients with obstetric complaints who were admitted to the Emergency Service at Akdeniz University Hospital. The study sample of the triage case study was calculated with reference to the formula suggested by Ineke van der Wulp (2010) while testing the OTAS for reliability. As indicated by Ineke van der Wulp (2010), the sample was calculated as $\mathrm{K} 1: 0.70, \alpha=0.05, \beta=0.80$, which included 10 nurses as assessors and 160 triage cases. The triage case studies were derived from the actual data of patients with obstetric complaints (3750) registered in the Hospital Information Management System (MiaMed ${ }^{\circledR}$ ) on 06.03.2017, that is, 1 year before the implementation of the study (01.01.201631.12.2016). Triage case study selection was retrospectively conducted by stratified random sampling monthly and as a result, 14 case studies were selected every month (160 case studies).

\section{Ethical considerations}

For the purposes of complying the ethical considerations that would ensure to protect the rights of individuals and avoid any harm, the researchers handed out a disclosure form to nurses who have the potential to participate in the study and voluntary nurses filled out and signed a consent form. The researchers also sought a permission in writing from Akdeniz University Clinical Research Ethics Committee (Accepted No: 469 Date: 09.08.2017) as well as from the office of the Chief Physician at Akdeniz University Hospital and Nancy Watts who is a author of the scale to be used in the study. 
JPH, April 2022, 7(1), 1-14

\section{Instruments}

The study data were collected with "Triage Case Studies," "Personal Information Form" and "the Obstetric Triage Acuity Scale."

\section{Triage Case Studies}

Brief triage case studies included medical history and acuity level of the obstetric patient who was considered useful for triage nurses. Triage case studies involved emergency delivery, vaginal bleeding, hypertension, trauma, fetal movement deficiency, pain, nausea, vomiting and upper respiratory tract infection. 160 triage case studies contained primary complaints, vital signs, Glaskow Coma Scale (GCS), Oxygen Saturation, bleeding and general medical condition. The case studies were initially chosen by 5 experts, who were an emergency medicine specialist, three specialist triage nurses, and a faculty member specialized in education. The researcher assessed the content of the case studies considering the expert opinions. To ensure the integrity of the content and the simplicity and clarity of language, the researcher has revised the case studies making necessary additions/subtractions before finalizing the scenarios.

\section{Personal Information Form}

The researchers developed a Personal Information Form in accordance with the recent data in literature, which included 12 items inquiring demographic characteristics such as age, gender, marital status, educational status, duration of professional service, and income status as well as whether or not they have received triage training before (Chagolla et al., 2013).

\section{The Obstetric Triage Acuity Scale (OTAS)}

The Obstetric Triage Acuity Scale was developed by Smithson et al. (2013) modeled on a 5-category CTAS instrument. The OTAS is scored as 1-most acute, 2-very acute, 3-acute, 4less acute 5-not acute. The scale consists of complaint-oriented triage sections including the time of assessment, medical complications and obstetric determinants. The OTAS was added two more sections, the substance use and mental health assessment, in 2016 in the National Study of Triage. Gratton et al. (2016) also added a final section to assess the patient's hemodynamic status (shock), respiratory stress, fetal evaluation (fetal heartbeat, meconium in amniotic fluid) and cervical dilatation to support the expert assessment of acuity. The scale was collected under three main headings and in the original it was determined as kappa, OTAS 1-4 0.61-0.77 and OTAS 50.87 (Smithson et al., 2013). 
$\mathrm{JPH}$, April 2022, 7(1), 1-14

\section{Data collection method}

Before collecting the data, initially, the triage case studies were developed and the expert opinions were obtained. Afterwards, 10 nurses who consented to participate in the study were randomly selected to form a working group in the triage unit at the emergency service. The data forms were completed via face-to-face interviews with the participants. The triage nurses were asked to complete the Personal Information Form during their application. To comply with the original OTAS form, Nancy Watts sent a presentation in English by email which was translated to Turkish by the researcher (Smithson et al., 2013). The nurses who agreed to participate in the study were divided into two groups and the researcher delivered a 30-minute presentation to introduce the Obstetric Triage Acuity Scale and demonstrated how to apply the scale. During the practice session, 10 nurses were given 160 written triage case studies and they were asked to evaluate the acuity of patients by using the OTAS. The case studies were read by the participants and their responses were recorded by the researcher. It took approximately 4550 minutes for each nurse to evaluate the case studies.

\section{Data analysis}

Statistical Package for the Social Sciences (SPSS) 20.0 and Statistical Analysis Software (SAS) were used to analyze the study data. The inter-rater reliability was evaluated with descriptive statistics such as mean, percentage, frequency, median (min-max) and Fleiss's Kappa coefficient tests. When adapting the OTAS to Turkish, it was also tested for language validity and internal validity.

\section{Language validity}

The researcher translated the Obstetric Triage Acuity from English to Turkish and the scale was also translated by three faculty members who were competent in English. The Turkish translation of the scale was revised once again by the researcher and her advisor. The translation was confirmed with "blind back translation" by a lecturer in the School of Foreign Languages at Akdeniz University to minimize differences in conceptualization and interlingual errors. Finally, the translation of the scale was sent to Nancy Watts, the author of the original scale, and it was revised in line of the suggestions of the author (Smithson et al., 2013).

\section{Internal validity}

The researcher required expert opinion to evaluate the internal validity of the OTAS. Thus, the researcher consulted with 8 faculty members to assess the Turkish translation of the scale. The experts were asked to evaluate the scale with the Content Validity Index that was developed by Waltz and Bausell in 1983 (Polit and Beck, 2006). The Index was designed as a 4- 
$\mathrm{JPH}$, April 2022, 7(1), 1-14

point likert form and it was scored as 1 "many revisions (as suggested)", 2 "few revisions (as suggested)", 3 "appropriate", 4 "very appropriate".

\section{RESULTS}

This section provides descriptive characteristics of nurses who consented to participate in the validity and reliability study of the OTAS in the triage unit at Akdeniz University Hospital Emergency Service as well as findings related to the validity and reliability analysis for the Turkish translation of the OTAS.

Table 1. Sociodemographic Characteristics of Triage Nurses in Emergency Units and Status of Triage Training (n:21)

\begin{tabular}{|c|c|c|c|}
\hline \multicolumn{2}{|l|}{ Sociodemographic Characteristics } & $\mathbf{n}$ & $\%$ \\
\hline \multirow[t]{3}{*}{ Age } & 19-28 years old & 9 & 42.9 \\
\hline & 29-38 years old & 12 & 57.1 \\
\hline & $\overline{\mathrm{x}} \pm \mathrm{SD}$ & $29.4 \pm 3.7$ & $-\max : 37)$ \\
\hline \multirow[t]{2}{*}{ Gender } & Female & 15 & 71.4 \\
\hline & Male & 6 & 28.6 \\
\hline \multirow[t]{2}{*}{ Marital Status } & Married & 12 & 57.1 \\
\hline & Single & 9 & 42.9 \\
\hline \multirow[t]{3}{*}{ Educational Status } & Vocational College & 3 & 14.3 \\
\hline & Undergraduate & 17 & 81 \\
\hline & Graduate & 1 & 4.7 \\
\hline The duration of Professional Service (Years) & $\overline{\mathrm{x}} \pm \mathrm{SD}$ & \multicolumn{2}{|c|}{$6.9 \pm 3.0 \quad$ (min: $2-\max : 14)$} \\
\hline $\begin{array}{l}\text { The duration of Professional Service in } \\
\text { Triage Unit (Years) }\end{array}$ & $\overline{\mathrm{x}} \pm \mathrm{SD}$ & \multicolumn{2}{|c|}{$4.3 \pm 2.2 \quad$ (min: 1-max:8) } \\
\hline \multirow[t]{2}{*}{ Status of Triage Training } & Yes & 17 & 81 \\
\hline & No & 4 & 19 \\
\hline \multirow[t]{4}{*}{ Status of Participating in Triage Events } & Congress/Symposium & - & \\
\hline & In-service training & 16 & 76.2 \\
\hline & Certificate Programs & 1 & 4.8 \\
\hline & All & 1 & 19 \\
\hline \multirow[t]{2}{*}{ Need for Triage Training } & Yes & 21 & 100 \\
\hline & No & & \\
\hline \multirow[t]{2}{*}{ Use of Triage Scales } & Yes & 21 & 100 \\
\hline & No & & \\
\hline Triage Scales & ESI/ATS & 21 & 100 \\
\hline
\end{tabular}

The participants were aged between 20 and 35 years and the mean age was $29.1 \pm 3.8$. Also, $50.0 \%$ of the participants were women, $60 \%$ of them were married and almost all of them $(90 \%)$ had an undergraduate degree. More than half of the participants' income (60\%) was equal to expenditure. The mean duration of professional service was $6.4 \pm 3.3$ and the mean duration of professional service in emergency triage units was $3.8 \pm 2.5$. It was also found that $80 \%$ of the nurses in the study took triage courses during nursing education; $60 \%$ of them reported that they received in-service training on triage. All the nurses (100\%) reported that the healthcare 
$\mathrm{JPH}$, April 2022, 7(1), 1-14

staff needed triage training courses and that they were mainly using two different triage scales, ESI (Emergency Severity Index) and ATS (Australian Triage Scale) (Table 1).

\section{Validity analysis of the Obstetric Triage Acuity Scale}

\section{Language validity}

The Turkish adaptation of the OTAS was first tested for language validity. The researcher translated the scale from English to Turkish and then, the scale was also translated by four faculty members. The translation of the OTAS was later revised by the researcher and her advisor. In order to minimize differences in conceptualization and interlingual errors, the translation was confirmed with "blind back translation" by a lecturer in the School of Foreign Languages at Akdeniz University who hadn't seen the original scale and who was competent in English. Eventually, the Turkish translation of the scale was revised again by the researcher and her advisor.

\section{Analysis of internal validity}

Each item in the scale was scored by the experts and these scores are presented in Table 2.

To confirm the internal validity of the scale, the researcher consulted with 8 experts to evaluate language validity who scored the translation of the scale as 1 "many revisions (as suggested)," 2 "few revisions (as suggested)," 3 "appropriate," 4 "very appropriate." The researcher revised the scale according to the expert opinions. As suggested in Table 2, average expert points ranged from 3 to 4 , minimum scores were between 2 and 4, and the maximum score was 4 . The Item Content Validity Index (I-CVI) for the simplicity and clarity of language was 0.983 , which was found to be above the average. The results of the scale content analysis further indicated that the scale content validity index (S-CVI) was noted to be agreeable between 0.80-0.90 and excellent when it was higher than 0.90. In this study, the Item Content Validity Index for the simplicity and clarity of language was 0.8636 , which suggested an almost perfect scale content validity.

The experts didn't only score the adaptation of the scale but also they commented on the clarity of statements and the integrity of the content. Accordingly, several items in the scale, 1st, 3rd, 5th, 10th, and 14th items, were revised and corrected to ascertain the integrity of the content and clarity in the language. 
Journal of Pre-Hospital - Hastane Öncesi Dergisi

JPH, April 2022, 7(1), 1-14

Table 2. The Expert Opinions on Obstetric Triage Acuity Scale (n:8)

\begin{tabular}{|c|c|c|c|c|c|}
\hline Items & $\mathbf{N}$ & $\overline{\mathbf{x}}$ & $\mathbf{S d}$ & $\begin{array}{c}\text { Minimu } \\
\mathbf{~}\end{array}$ & Maximum \\
\hline $\mathbf{1}$ & 8 & 3.7500 & 0.46291 & 3.00 & 4.00 \\
\hline $\mathbf{2}$ & 8 & 4.0000 & 0.00000 & 4.00 & 4.00 \\
\hline $\mathbf{3}$ & 8 & 3.7500 & 0.46291 & 3.00 & 4.00 \\
\hline $\mathbf{4}$ & 8 & 3.8750 & 0.35355 & 3.00 & 4.00 \\
\hline $\mathbf{5}$ & 8 & 3.1250 & 0.35355 & 3.00 & 4.00 \\
\hline $\mathbf{6}$ & 8 & 3.6250 & 0.51755 & 3.00 & 4.00 \\
\hline $\mathbf{7}$ & 8 & 3.7500 & 0.46291 & 3.00 & 4.00 \\
\hline $\mathbf{8}$ & 8 & 3.3750 & 0.51755 & 3.00 & 4.00 \\
\hline $\mathbf{9}$ & 8 & 3.7500 & 0.46291 & 3.00 & 4.00 \\
\hline $\mathbf{1 0}$ & 8 & 3.1250 & 0.64087 & 2.00 & 4.00 \\
\hline $\mathbf{1 1}$ & 8 & 3.3750 & 0.51755 & 3.00 & 4.00 \\
\hline $\mathbf{1 2}$ & 8 & 3.7500 & 0.46291 & 3.00 & 4.00 \\
\hline $\mathbf{1 3}$ & 8 & 3.6250 & 0.51755 & 3.00 & 4.00 \\
\hline $\mathbf{1 4}$ & 8 & 3.2500 & 0.70711 & 2.00 & 4.00 \\
\hline $\mathbf{1 5}$ & 8 & 3.5000 & 0.53452 & 3.00 & 4.00 \\
\hline $\mathbf{1 6}$ & 8 & 3.3750 & 0.74402 & 2.00 & 4.00 \\
\hline $\mathbf{1 7}$ & 8 & 3.8750 & 0.35355 & 3.00 & 4.00 \\
\hline $\mathbf{1 8}$ & 8 & 3.8750 & 0.35355 & 3.00 & 4.00 \\
\hline $\mathbf{1 9}$ & 8 & 3.5000 & 0.53452 & 3.00 & 4.00 \\
\hline $\mathbf{2 0}$ & 8 & 4.0000 & 0.00000 & 4.00 & 4.00 \\
\hline $\mathbf{2 1}$ & 8 & 3.6250 & 0.51755 & 3.00 & 4.00 \\
\hline $\mathbf{2 2}$ & 8 & 3.5000 & 0.53452 & 3.00 & 4.00 \\
\hline
\end{tabular}

\section{Reliability analysis of the Obstetric Triage Acuity Scale}

The reliability of the OTAS was evaluated with the inter-rater reliability using Fleiss Kappa coefficient analysis. Table 3 demonstrates the scores of the triage nurses evaluating the OTAS and the actual scores of the scale.

Table 3. The Analysis of the Scores of the Nurses and the Actual Scores of the Scale (n:10)

\begin{tabular}{|c|c|c|c|c|}
\hline Level & Kappa & Sd & $\mathbf{Z}$ & $\mathbf{P}$ \\
\hline 1 & 0.53357 & 0.010660 & 50.0537 & 0.0001 \\
\hline 2 & 0.36454 & 0.010660 & 34.1966 & 0.0001 \\
\hline 3 & 0.41656 & 0.010660 & 39.0764 & 0.0001 \\
\hline 4 & 0.36874 & 0.010660 & 34.5909 & 0.0001 \\
\hline 5 & 0.42128 & 0.010660 & 39.5193 & 0.0001 \\
\hline Overall OTAS & 0.42271 & 0.006003 & 70.4146 & 0.0001 \\
\hline $\begin{array}{l}\text { Kendall } \\
\text { Coefficient } \\
\text { Concordance }\end{array}$ & $\mathbf{F}$ & SD & SD & $\mathbf{P}$ \\
\hline 0.73352 & 27.53 & 158.818 & 1588.18 & 0.0001 \\
\hline
\end{tabular}

General Kappa and Kendall's coefficient of concordance were used to correlate the scores of the triage nurses and the actual scores of the scale and the results of both analysis were found to be statistically significant which indicated that inter-rater agreement was stronger than expected (Kendall $\mathrm{W}=0.733, \mathrm{p}=0.001$ ). The kappa results represent the degree of concordance 
$\mathrm{JPH}$, April 2022, 7(1), 1-14

of each category and Level 1 showed the strongest concordance followed by levels 5, 3, 4, and 2 , respectively.

Table 4 shows the scores of 10 triage nurses who evaluated the Obstetric Triage Acuity Scale. General Kappa and Kendall's coefficient of concordance were reported to be both statistically significant, which suggested a stronger inter-rater agreement than expected (Kendall $\mathrm{W}=0.733, \mathrm{p}=0.001)$. The results of the kappa analysis further confirmed that level 1 showed the strongest concordance followed by levels $5,3,4$, and 2 , respectively.

Table 4. The Scores of the Nurses Evaluating the OTAS (n:10)

\begin{tabular}{|c|r|r|r|r|}
\hline Level & Kappa & Sd & z & P \\
\hline 1 & 0.50473 & 0.011785 & 42.8277 & 0.0001 \\
\hline 2 & 0.32148 & 0.011785 & 27.2789 & 0.0001 \\
\hline 3 & 0.37610 & 0.011785 & 31.9128 & 0.0001 \\
\hline 4 & 0.32900 & 0.011785 & 27.9165 & 0.0001 \\
\hline 5 & 0.38671 & 0.011785 & 32.8133 & 0.0001 \\
\hline Overall OTAS & 0.38520 & 0.006637 & 58.0361 & 0.0001 \\
\hline $\begin{array}{c}\text { Kendall } \\
\text { Coefficient of } \\
\text { Concordance }\end{array}$ & F & SD & SD & P \\
\hline 0.72174 & 23.34 & 158.8 & 1429.2 & 0.0001 \\
\hline
\end{tabular}

The results in Table 5 demonstrate the simple and weighted Kappa coefficients of concordance between the scores of the participant nurses and the actual scores of the OTAS. Both the simple and weighted Kappa agreement coefficients were reported to be statistically significant and a strong correlation was found between the scores given by the experts and the actual scores of the scale (Simple Kappa: 0.7956 and weighted Kappa: 0.9185).

Table 5. The Analysis of the Scores of the Nurses and the Actual Scores of the OTAS (n:10)

\begin{tabular}{|l|r|r|}
\hline & $\begin{array}{c}\text { Simple Kappa } \\
\text { Coefficient }\end{array}$ & $\begin{array}{c}\text { Weighte Kappa } \\
\text { Coefficient }\end{array}$ \\
\hline Kappa & 0.7956 & 0.9185 \\
\hline Standard Deviation & 0.0384 & 0.0197 \\
\hline $\mathbf{9 5 \%}$ lower confidence limit & 0.7203 & 0.8799 \\
\hline $\mathbf{9 5 \%}$ higher confidence limit & 0.8709 & 0.9571 \\
\hline Z & 17.4901 & 11.6858 \\
\hline One way p & 0.0001 & 0.0001 \\
\hline
\end{tabular}

\section{DISCUSSION}

It has been widely suggested that special triage systems are needed to determine the acuity of obstetric patients in emergency services and the OTAS was primarily designed to establish a specific-triage system to correspond to the special needs of obstetric patients. 
$\mathrm{JPH}$, April 2022, 7(1), 1-14

The results of the analysis suggested that the Item Content Validity Index (I-CVI) was 0.983, which was found to be above the average. Also, the Scale Content Validity Index (SCVI) was 0.8636 concerning the simplicity and clarity of language that similarly indicated almost perfect scale content validity. The internal validity of scales is often confirmed with ICVI and S-CVI scores of 0.80 and above (Polit and Beck, 2006). Ruhl et al. (2015), for instance, tested MFTI for validity and found that the I-CVI score was 0.82 and the S-CVI score was 0.95 , which already complied with the results of our analysis. These results demonstrate that the experts agreed with the internal validity of the scale, and that the scale was suitably adapted for Turkish culture. As a result, it could be suggested that the internal validity of the Obstetric Triage Acuity Scale was successfully achieved.

To conduct the reliability analysis of the OTAS, inter-rater reliability was comprehensively evaluated. Since the clinical condition of the patients in emergency services may abruptly and unexpectedly change, the inter-rater reliability was the most commonly available measure to verify the scale (Worster et al., 2004; Fernandes et al., 2005; Olofsson et al., 2008; Grouse et al., 2008; Taboulet et al., 2009; Van der Wulp and Stel, 2010; McHugh, 2012; Parenti et al., 2014). The results of this study suggested that both simple and weighted kappa coefficients of concordance were statistically significant, and a strong correlation was reported between the scores of the participant nurses and the actual scores of the scale $(0.7$ : 0.7956 and weighted Kappa: 0.9185). Smithson et al. (2013) similarly reported that the kappa value of the original scale was 0.7147. Kenyon et al. (2017) also noted an excellent inter-rater reliability (ICC 0.961 (95\% CI 0.91-0.99)) in a study on the obstetric triage system reliability in a delivery unit in the UK.

The results of our study further complied with the results of reliability studies conducted using many triage scales in emergency services such as ATS, EU, CTAS, SETS, FRENCH, MCT and the Triage and Color Coding designed by the Ministry of Health in Turkey. Erimşah et al., (2017) carried out a study to evaluate the inter-rater reliability and validity of the Triage and Color Coding designed by the Turkish Ministry of Health with 618 actual patients and reported a quadratic weighted kappa value of 0.725 (95\% CI 0.68-0.77) which was concluded to be statistically significant. Likewise, in a relevant study conducted in Turkey, the reliability of a triage system, TraumaKS, was found to be almost perfect in terms of inter-rater reliability and validity compared to the results of similar studies (Weighted Kappa Value: 0.862) (Akdoğan, 2018). Rutschmann et al. (2018) also carried out a study with 3387 patients and stated that the Swiss Emergency Triage Scale (SETS) indicated a significant inter-rater agreement (mean 0.6: 0.68; 95\% confidence interval (CI): 0.60-0.78). Moreover, Gerdtz et al found a kappa value of 0.412 in a study conducted with 237 case studies using the ATS and they 
JPH, April 2022, 7(1), 1-14

reported a lower level of agreement in case studies, particularly involving psychiatric and obstetric patients $(\kappa=0.243,95 \%$ CI $0.237-0.249 ; \kappa=0.319,95 \%$ CI $0.310-0.328)$ (Gerdtz et al., 2008). Taboulet et al. (2009) carried out a study with actual patients in France by using FRENCH version 2 and found that the weighted kappa value was 0.77 for inter-rater reliability. In a similar study, the researchers reported a significant level of inter-rater reliability in a study conducted with ESI version 2 with a kappa value ranging from 0.70 to 0.80 (Eitel et al., 2003). Pourasghar et al. (2015) noted linear weighted kappa and quadratic kappa weights of 0.312 (95\% CI: $0.253-0.370)$ and 0.482 (95\%) in their study with ESI. Furthermore, In a recent study conducted with ESI version 4, the kappa value was 0.73 (Mistry et al., 2018). The Canadian Triage Acuity Scale (CTAS) was tested for reliability and the kappa value was found to be 0.73 by Fernandes et al. (2013) and 0.87 by Alquraini et al. (2015). Dalwai et al. (2014), on the other hand, tested the South African Triage Scale for reliability and found the kappa value as 0.77. Recent meta-analyzes have indicated that kappa coefficients for CTAS, ESI, MTS and ATS were 0.67, 0.79, 0.75 and 0.42, respectively (Ebrahimi et al., 2015; Mirhaghi et al., 2015; Mirhaghi et al., 2017).

\section{CONCLUSIONS}

Therefore, it could be concluded that there was a strong inter-rater agreement in the reliability assessments of the Turkish adaptation of OTAS Turkish and it could be recommended as a reliable triage scale.

\section{Author Contributions}

Concept EG, KK; Design EG, KK; Materials EG, KK; Data Collection\&/or Processing EG, KK; Analysis/Interpretation EG, KK; Literature Search EG, KK; Writing EG, KK.

\section{Conflict of Interest}

There isn't any conflict of interest.

\section{Acknowledgments}

We are grateful to everyone who participated in the study and to my teacher. 
$\mathrm{JPH}$, April 2022, 7(1), 1-14

\section{References}

Akdoğan, A. (2018). Evaluation of the reliability and validity of digital triage with the help of computer software for trauma patients in the emergency department. Health Sciences University Kocaeli Derince Health Application and Research Center Department of Emergency Medicine. Kocaeli.

Alquraini, M, Awad, E, Hijazi, RE. (2015). Reliability of Canadian Emergency Department Triage and Acuity Scale (CTAS) in Saudi Arabia. International Journal of Emergency Medicine, 8(1), 29.

Angelini, DJ, LaFontaine, D. (2017). Obstetric triage. Editors Angelini, D, J, LaFontaine, D. Obstetric Triage and Emergency Care Protocols. 1 st ed. Springer. New York. p:1-21.

Association of Women's Health, Obstetric \& Neonatal Nurses (AWHONN) (2014). Women's health and perinatal nursing care quality refined draft measures specifications. Washington, DC: Access: https://www.awhonn.org/awhonn/content.do?name=02_PracticeResources/02_perinatalquality measures.htm, 20.04.2018.

Chagolla, BA, Keats, JP, Fulton, JM. (2013). The importance of interdepartmental collaboration and safe triage for pregnant women in the emergency department. JOGNN, 42(5), 595-605.

Dalwai, MK, Twomey, M, Maikere, J, Wakeel, M, Jemmy, JP, Valles, P, Zachariah, R. (2014). Reliability and accuracy of the south african triage scale when used by nurses in the emergency department of timergara hospital, Pakistan. South African Medical Journal, 104(5), 372-375.

Ebrahimi, M, Heydari, A, Mazlom, R, Mirhaghi, A. (2015). The reliability of the Australasian Triage Scale: A meta-analysis. World Journal of Emergency Medicine, 6(2), 94.

Eitel, DR, Travers, D, A, Rosenau, AM, Gilboy, N, Wuerz, RC. (2003). The Emergency Severity Index Triage algorithm version 2 is reliable and valid. Academic Emergency Medicine, 10(10), 1070-1080.

Emergency Nurses Association (ENA) (2011). Triage qualifications. Position statement. Des Plaines, IL: Access: https://www. ena.org/SiteCollectionDocuments/Position\%20Statements/ TriageQualifications.pdf, 12.05.2018.

Erimşah, ME, Yaka, E, Yılmaz, S, Kama, A, Pekdemir, M. (2015). Interrater reliability and validity of the Ministry of Health of Turkey's Mandatory Emergency Triage Instrument. Emergency Medicine Australasia, 27(3), 210-215.

Esin, MN. (2015). Data collection methods and tools \& reliability and validity of data collection tools. Erdogan S, Nahcivan N, Esin MN, eds. Research in Nursing. 2. Printing. Nobel Bookstore. Istanbul. 229230.

Evans, MK, Watts, N, Gratton, R. (2015). Women's satisfaction with obstetric triage services. JOGNN, 44(6), 693-700. 
$\mathrm{JPH}$, April 2022, 7(1), 1-14

Fernandes, CM, Tanabe, P, Gilboy, N, Johnson, LA, McNair, RS, Rosenau, AM, Sawchuk, P, Thompson, DA, Travers, DA, Bonalumi, N, Suter, RE. (2005). Five-level triage: a report from the ACEP/ENA Fivelevel Triage Task Force. J Emerg Nurs, 31(1), 39-50.

Fernandes, CM, McLeod, S, Krause, J, Shah, A, Jewell, J, Smith, B, Rollins, L. (2013). Reliability of the Canadian Triage and Acuity Scale: Interrater and intrarater agreement from a community and an academic emergency department. Canadian Journal of Emergency Medicine, 15(4), 227-232.

Gerdtz, MF, Collins, M, Chu, M, Grant, A, Tchernomoroff, R, Pollard, C, Wassertheil, J. (2008). Optimizing triage consistency in Australian emergency departments: The emergency triage education kit. Emergency Medicine Australasia, 20(3), 250-259.

Gratton, RJ, Bazaracai, N, Cameron, I, Watts, N, Brayman, C, Hancock, G, Twohey, R, Alshanteer, S, Ryder, JE, Basso, M, Smithson, DS. (2016). Acuity assessment in obstetrical triage. Journal Obstet Gynaecol Can, 38(2), 125-133.

Grouse, AI, Bishop, RO, Bannon, AM. (2009). The Manchester Triage System provides good reliability in an Australian emergency department. Emerg Med J, 26(7), 484-486.

Hinson, JS, Martinez, DA, Schmitz, PS, Toerper, M, Radu, D, Scheulen, J, Levin, S. (2018). Accuracy of emergency department triage using the Emergency Severity Index and independent predictors of undertriage and over-triage in Brazil: A retrospective cohort analysis. International Journal of Emergency Medicine, 11(1), 3.

Kenyon, S, Hewison, A, Dann, SA, Easterbrook, J, Hamilton-Giachritsis, C, Beckmann, A, Johns, N. (2017). The design and implementation of an obstetric triage system for unscheduled pregnancy related attendances: A mixed methods evaluation. BMC Pregnancy and Childbirth, 17(1), 1-10.

Kılıç, S. (2015). Kappa Test. Journal of Mood Disorders, 5(3), 142-144.

McHugh, ML. (2012). Interrater reliability: The kappa statistic. Biochem Med, 22(3), 276-282.

Mirhaghi, A, Mazlom, R, Heydari, A, Ebrahimi, M. (2017). The reliability of the Manchester Triage System (MTS): A meta-analysis. Journal of Evidence Based Medicine, 10(2), 129-135.

Mistry, B, De Ramirez, SS, Kelen, G, Schmitz, PS, Balhara, KS, Levin, S, Hinson, JS. (2018). Accuracy and reliability of emergency department triage using the emergency severity index: an international multicenter assessment. Annals of Emergency Medicine, 71(5), 581-587.

Olofsson, P, Gellerstedt, M, Carlström, ED. (2009). Manchester Triage in Sweden interrater reliability and accuracy. International Emergency Nursing, 17(3), 143-148.

Paisley, KS, Wallace, R, DuRant, PG. (2011). The development of an Obstetric Triage Acuity Tool. MCN Am J Matern Child Nurs, 36(5), 290-296.

Panicker, S. (2014). Is obstetric triage necessary? International Journal of Reproduction, Contraception, Obstetrics and Gynecolo, 3(1), 44-47. 
$\mathrm{JPH}$, April 2022, 7(1), 1-14

Parenti, N, Reggiani, MLB, Iannone, P, Percudani, D, Dowding, D. (2014). A systematic review on the validity and reliability of an emergency department triage scale, the Manchester Triage System. International Journal of Nursing Studies, 51, 1062-1069.

Polit, DF, Beck, CT. (2006). The content validity index: are you sure you know what's being reported? Critique and recommendations. Research in Nursing \& Health, 29(5), 489-497.

Pourasghar, F, Daemi, A, Tabrizi, JS, Ala, A. (2015). Research article nurse-physician agreement on triage category: A reliability estimation of Emergency Severity Index. International Journal of Hospital Research, 4(4), 167-170.

Roukema, J, Steyerberg, EW, van Meurs, A, Ruige, M, van der Lei, J, Moll, HA. (2006). Validity of the Manchester Triage System in paediatric emergency care. Emerg Med J, 23(12), 906-910.

Ruhl, C, Scheich, B, Onokpise, B, Bingham, D. (2015). Interrater reliability testing of the Maternal Fetal Triage Index. Journal of Obstetric, Gynecologic \& Neonatal Nursing, 44(6), 710-716.

Rutschmann, OT, Hugli, OW, Marti, C, Grosgurin, O, Geissbuhler, A, Kossovsky, M, Sarasin, FP. (2018). Reliability of the revised Swiss Emergency Triage Scale: A computer simulation study. European Journal of Emergency Medicine, 25(4), 264.

Smithson, DS, Twohey, R, Rice, T, Watts, N, Fernandes, CM, Gratton, RJ. (2013). Implementing an obstetric triage acuity scale: Interrater reliability and patient flow analysis. American Journal of Obstetric \& Gynecology, 209(4), 287-293.

Taboulet, P, Moreira, V, Haas, L, Porcher, R, Braganca, A, Fontaine, JP, Poncet, MC. (2009). Triage with the French Emergency Nurses Classification in Hospital Scale: Reliability and validity. European Journal of Emergency Medicine, 16(2), 61-67.

Worster, A, Gilboy, N, Fernandes, CM, Eitel, D, Eva, K, Geisler Tanebe, P. (2004). Assessment of interobserver reliability of two five-level triage and acuity scales: A randomized controlled trial. Can J Emerg Med, 6(4), 240-245.

Wulp, I, Stel, HF. (2010). Calculating kappas from adjusted data improved the comparability of the reliability of triage systems: a comparative study. Journal of Clinical Epidemiology, 63(11), 1256-1263.

van der Wulp, I. (2010). Reliability and validity of emergency department triage systems. Enschede, the Netherlands: Gildeprint Drukkerijen, 45-50.

Van der Wulp, I, Schrijvers, AJP, Van Stel, HF. (2009). Predicting admission and mortality with the Emergency Severity Index and the Manchester Triage System: A retrospective observational study. Emergency Medicine Journal, 26(7), 506-509.

van Veen, M, Moll, HA. (2009). Reliability and validity of triage systems in paediatric emergency care. Scandinavian Journal of Trauma, Resuscitation and Emergency Medicine, 17(1), 38. 